\title{
Language policy, multilingual education, and power in Rwanda
}

\author{
Beth Lewis Samuelson • Sarah Warshauer Freedman
}

Received: 19 May 2009/Accepted: 2 May 2010/Published online: 8 June 2010

(C) The Author(s) 2010. This article is published with open access at Springerlink.com

\begin{abstract}
The evolution of Rwanda's language policies since 1996 has played and continues to play a critical role in social reconstruction following war and genocide. Rwanda's new English language policy aims to drop French and install English as the only language of instruction. The policy-makers frame the change as a major factor in the success of social and education reforms aimed at promoting reconciliation and peace and increasing Rwanda's participation in global economic development. However, in Rwanda, the language one speaks is construed as an indicator of group affiliations and identity. Furthermore, Rwanda has the potential to develop a multilingual educational policy that employs its national language, Kinyarwanda (Ikinyarwanda, Rwanda), to promote mass literacy and a literate, multilingual populace. Rwanda's situation can serve as a case study for the ongoing roles that language policy plays in the politics of power.
\end{abstract}

Keywords Language-in-education policy · Rwanda · French · Kinyarwanda · Africa

Near the end of 2008, some international news coverage focused on Rwanda's announcement that it was discarding French as one of its three official languages. Rwanda would now have only two official languages: Kinyarwanda and English (McCrummen, 2008; National Public Radio, 2008). French, the language left by

B. L. Samuelson $(\bowtie)$

Department of Literacy, Culture and Language Education, School of Education, Indiana University, 201 N. Rose, \#3022, Bloomington, IN 47405, USA

e-mail: blsamuel@indiana.edu

S. W. Freedman

Graduate School of Education, University of California,

Berkeley, CA 94720-1670, USA

e-mail: freedman@berkeley.edu 
Belgian colonial powers who began the school system, would no longer be a medium of instruction in the schools and universities, nor would it serve any longer as an official language in public affairs. In typical fashion for this strictly hierarchical political system, the top-down decision was made with the expectation that the public would dutifully make the shift, completing a process that had been started 14 years earlier when the victorious Rwandan Patriotic Front (RPF) added English as an official language in 1996 soon after taking power in the wake of the 1994 wars and genocide.

Policy-makers in Rwanda see the new language policy as a major factor in the success of Rwanda's post-genocide reforms. We see the reforms as also risky and wish to employ this situation as a case study for the impact of globalization on the study of English worldwide. The Rwandan government is justifying the switch to English as a medium of instruction by pointing to the global and regional growth of English as the leading language of science, commerce and economic development. The government claims that greater prosperity will contribute to national reconciliation by improving living standards and life opportunities for all Rwandans. These claims are misleading in several ways, each of which we will address in this article. First, claiming that English will contribute to reconciliation by promoting economic growth overlooks the ways that language use is linked to identity amongst Rwanda's elites. Second, claiming that early English education will lead to greater participation in the global economy, and therefore to improved living conditions and prospects for educational advancement, overlooks the ideological implications of the spread of English as a global language. Finally, the desired outcomes of a rapid and early switch to English as the medium instruction are likely not to be realized for the majority of Rwandan students, leaving many with added disadvantages.

Since 2001, we have made numerous trips to Rwanda, first to organize and collect data for a project on the role of education in social reconstruction following the 1994 wars and genocide (Freedman et al. 2004; Stover and Weinstein 2004; Weinstein et al. 2007), and later to work on a project to produce materials for teaching Rwandan history (Freedman et al. 2008). In addition, Samuelson has been involved in research on language and literacy education in Rwanda since 2006. Throughout we have been investigating the impact of language policy changes.

\section{A comprehensive examination of the development of Rwanda's language policy}

In this section we trace the chronology of language use in Rwanda leading up to the decision to drop French as an official language in 2008. We begin first with a discussion of the Kinyarwanda language, then with a discussion of the introduction and uses of French and English.

Kinyarwanda: the everyday language

In Rwanda today, Kinyarwanda is described as a critical element in the essence of "Rwandan-ness." Rwandans believe that all Rwandans should speak 
Kinyarwanda. They will scold Rwandans who do not speak it well, most of whom were displaced by the wars and massacres prior to 1994 and who grew up outside Rwanda (often called the Diaspora). The fact that Rwanda has only one autochthonous language makes it a special case, as most African nations are multilingual. Thus, Kinyarwanda is viewed as a unifier. As high as $99.4 \%$ of the population can speak Kinyarwanda (Rosendal 2009), and approximately $90 \%$ of Rwandans speak only Kinyarwanda (LeClerc 2008; Munyankesha 2004).

Kinyarwanda is the language of instruction in primary schools and is frequently spoken in daily life and at official public functions (The New Times 2007b). Despite the widespread use of Kinyarwanda, mass literacy in Kinyarwanda remains weak: relatively few high-quality textbooks and books with popular appeal are available in Kinyarwanda. While some periodicals and newspapers in Kinyarwanda are in circulation, the main vehicle for communication with the masses who speak only the vernacular is through radio and television. An indication of this disparity with English and French comes from a recent study of billboards and signs in which Kinyarwanda ranked below both Western languages in the frequency of use (Rosendal 2009).

In respect to mass literacy, Kinyarwanda has received some of the benign neglect that has been the fate of many other African languages, as French was retained as the language of prestige and political power immediately after independence. Kinyarwanda has remained less developed because it is not the language of instruction beyond primary school (Rassool 2007). Primary school graduates who are able to move on to secondary school go through a form of transitional bilingualism as they shift from learning in their mother tongue to learning in an excolonial language. So while Kinyarwanda does enjoy the unique advantage of being the only non-colonial language widely spoken in Rwanda, it is not the primary language of cultural, social and economic capital.

Varieties of Kinyarwanda are also spoken beyond Rwanda's borders. Speakers of Kinyarwanda or languages similar to Kinyarwanda live in southern Uganda, eastern Congo, and western Tanzania (Munyankesha 2004). Kirundi, the language of Burundi, Rwanda's neighbor to the south, is mutually intelligible with Kinyarwanda (Masagara 2001). The name "Ururimi," which simply means "language" or "tongue" (Niyomugabo 2009), has been used to describe the language features shared by this community of speakers both inside and outside of Rwanda (e.g., The New Times 2008). The Kinyarwanda Computing Project to adapt Kinyarwanda for software applications has been renamed the Ururimi Computing Project and includes vocabulary from both Kinyarwanda and Kirundi. The BBC Radio, Rwanda Radio and Burundi Radio are broadcasting call-in programs that allow people to voice their opinions in "Kinyarwanda/Kirundi."

French: the colonial inheritance

When Rwanda was a Belgian colony from 1890-1962, the Belgians brought French as an official new language. Reflecting its colonial past, Rwanda retained French as an official language following independence from Belgium. Until 1994, Rwanda was considered a Francophone country and was a member of La Francophonie, the 
worldwide 'club' of French-speaking countries (LeClerc 2008). Since the wars and genocide, though, acrimony between France and Rwanda has grown fierce. Indictments have been filed in French courts against Rwandan Patriotic Front (RPF) soldiers for massacres and against President Paul Kagame for allegedly shooting down former President Juvenale Habyarimana's plane, a key triggering event for the 1994 genocide. In response to these allegations, Rwanda accused France of supporting the genocidal (French-speaking) government through Operation Turquoise, a military intervention where French troops entered Rwanda in the last weeks of the genocide and reportedly aided the genocidaires (Mamdani 2001; Wallis 2006). Widespread bitterness over these wrongs has resulted in French being regarded as the language of the 1994 killers. It is seen as the language of Hutu who lived in Rwanda prior to the wars and genocide and of those implicated as criminals whether or not they participated in the violence. The 2008 arrest of Kagame's chief of protocol and former RPF officer, Rose Kabuye, resulted from the French indictments and is widely speculated to be a triggering event for the decision to drop French altogether (McGreal 2008). Also, Rwanda views Anglophone countries as more reliable sources of development aid and knowledge transfer than France, Belgium or their African allies. ${ }^{1}$

French has been waning in influence since 1994. However, even today it still maintains a dominant presence. For instance, in the linguistic landscape of billboard advertising and shop signs, it is used more frequently than English or Kinyarwanda (Rosendal 2009). This presence is indicative of the fact that French is more widely understood than English among the literate populace. French speakers include not just Hutu genocidaires but also Tutsi genocide survivors, Tutsi returnees from Francophone countries, and moderate Hutu who did not participate in the genocide.

The foundation for English 1994 to present: new identities and ideologies

English is the language of the victors, the Ugandan Tutsi RPF members who organized and led the invasion of Rwanda that stopped the genocide. Following the genocide, many former exiles began returning to Rwanda to resettle, from Uganda, Democratic Republic of Congo, Burundi, Tanzania, Kenya, South Africa as well as from countries outside Africa. Some of the returnees spoke French but more spoke English, not French. The formal adoption of English came in 1996 with the addition of English as an official language, accorded equal status with French and Kinyarwanda (LeClerc 2008).

By some estimates, the number of returnees from the Diaspora meets or exceeds the number of people killed during the wars and genocide (Prunier 2009a), some 500,000 to 800,000 people. Since most members of the RPF grew up in exile in Uganda or Tanzania, they are English speakers, many hold powerful positions, and many have little interest in learning French. Estimates of the percentage of English speakers in Rwanda today range from 1.9-5\% (LeClerc 2008; Munyankesha 2004); almost all are returnees. Another 3-5\% of Rwandans are French speakers, and most

\footnotetext{
1 The idea of an "Anglo-Saxon plot" to expand the influence of English to overtake French in Francophone countries has circulated among some French-speaking scholars. That Rwanda stands on the "linguistic Maginot line" between Francophone Africa to the west (D.R. Congo) and Anglophone Africa to the east (East African Union) is viewed as support for this conspiracy theory (LeClerc 2008).
} 
were in Rwanda before and during the genocide, although some are returnees, mostly from the Democratic Republic of Congo (Rosendal 2009). Although the exact numbers are uncertain, there is agreement that these English and French speakers are members of two small rival elites (Hintjens 2008).

\section{The new language policy}

In the trilingual Rwanda of 1996-2008, advanced primary and secondary students were able to use English or French as their primary language of instruction, and take Kinyarwanda and the other language as subjects. Students entering the university were expected to do academic work equally well in both English and French. This official plan, however, was far from the reality of an educational system struggling to recover from the devastating losses of teachers, materials and buildings.

This situation where French and English enjoyed equal status, at least in theory, came to an end in late 2008 when Rwanda announced that French would no longer be an official language. The Ministry of Education then announced a move to English as the sole medium of instruction (Gahigi 2008), with children beginning to study in English from the first grade. Secondary school entrance exams, which sixth graders must pass if they wish to continue studying, would be in English only. Secondary and tertiary education would also use English as the medium of instruction, with Kinyarwanda taught as a subject.

Today, 14 years after the end of the wars and genocide, many Rwandan elites have learned some English, but the language remains largely the domain of the elite and powerful Anglophones, mostly Ugandan returnees. Access to the necessary resources for learning English is limited and beyond the means of most Rwandans, including the Francophone elites. Since the policy change, many private institutes offering English instruction have opened, but their fees are high.

Primary school teachers at French-dominant schools must now take night and weekend classes in English, as they simultaneously try to pass their new skills on to their students during the day. These efforts are described as heroic by the local press, but in reality the teachers must comply or risk losing their jobs. At the university level, students at the Kigali Institute of Education learned from their rector that all classes would be conducted in English. Beginning in 2009, they would have to pass their examinations in English. Other universities have followed suit (Mugabe 2009; Nambi 2008).

Buy-in from the populace is reportedly due to the promised economic benefits, but in reality anyone who speaks openly against the policy faces retribution. Criticism of government policy is not tolerated. Political dissidents who lived in Rwanda before the genocide are likely to be Francophone and are effectively silenced by the switch to English. In the past, any suggestion of dissent over language policies has been promptly dismissed by the government (Gahindiro 2007). The Kagame government has done much to develop Rwanda's economy and improve the lives of many citizens, but it is increasingly censured internationally for its intolerance of dissent (Hintjens 2008; Longman and Rutagengwa 2004; Prunier 2009b) and for its involvement in the Congo war (Gettleman 2008; Hintjens 2008). 
The Rwandan conflict is best seen as an identity conflict similar to conflicts in Israel/Palestine, Mozambique, Northern Ireland, Sri Lanka, and the former Yugoslavia. In an identity conflict, economic disparities, class conflicts, language differences, and unequal access to public goods like higher education and whitecollar jobs are some of the possible factors contributing to the conflict. To speak of the Rwandan genocide as only an ethnic conflict is to obscure the political, social and economic issues that contributed to the violence; to speak of the new language policies as unrelated to those conflicts is to obscure the close relationships between language and identity and between language and ongoing political, societal, and economic conflicts.

\section{Changing the social discourse on identity}

Despite the complexity of the ethnicity issue, Rwanda does not take an identity perspective on ethnicity, but asserts that ethnicity does not exist within its borders. The public cannot discuss ethnicity openly, and as a result language preferences have become a proxy for identity, particularly among the elites. Therein lies the key link between ethnicity and language choice in Rwanda. In order to understand Rwanda's language policy, it is important to examine the government's stance towards ethnicity and its initiative to change the way that Rwandans perceive their group affiliations. Rwanda's language policies and the ways that they have changed offer important insights into the roles that ethnicity continues to play in Rwandan society. This linkage is most apparent in the role that language plays in Rwanda's efforts to "eradicate genocide ideology."

Genocide ideology and language policy

Since the end of the wars and genocide, the Kagame government has asserted that all Rwandans are first and foremost citizens of Rwanda and that the sharp divisions over ethnicity are a legacy of colonization under the Belgians. They assert that since Rwandans share Kinyarwanda in common, they are therefore of the same ethnic group. Denial of the existence of ethnicity in Rwanda makes any national discourse on differences impossible.

The origins of Rwanda's three groups (Hutu, Tutsi, and Twa), and their actual reality in the daily existence of most Rwandans, are a source of ongoing controversy, now carried on mainly outside of Rwanda's borders as public discourse on these topics is suppressed inside the country (Eltringham 2004). Part of the reason for the seemingly irreconcilable differences about the origins of Rwanda's ethnic groups has to do with the lack of solid information on pre-historical migration patterns, which are known only through limited archeological research. Archeological findings often appear to conflict with oral history accounts, and are ambiguous enough to leave the door open for many different politically convenient interpretations, each reflecting the ethnic and social affiliations of their authors (Longman 1999). 
The powerful official narrative about the origins of the divisions in Rwandan society contends that colonial rule was the source of conflict. The narrative goes like this: although perceptions of group differences based on social class and wealth may have existed prior to colonial occupation, they were deliberately racialized by European colonists and missionaries and their Rwandan collaborators for the purpose of gaining political control (Mamdani 2001). The intentional misuse of existing distinctions to divide Rwandan society fostered deep resentments and a strong sense of inferiority on the part of the Hutu, with deadly consequences. The Tutsi were given positions of power and access to European-style education under the Belgian colonials, but in the years leading up to independence the Hutu majority gained power. By the time of independence, they had systemically marginalized the Tutsi minority in education, bureaucracy, and politics. The period from 1959 to 1994 was punctuated by regular outbreaks of pogroms and massacres directed against the Tutsi, causing many to flee to neighboring countries (Prunier 1995). ${ }^{2}$

These assertions, that the violent divisions that eventually culminated in the genocide were the result of colonial meddling and in fact that ethnic identity in Rwanda is non-existent, rely on a restricted view of ethnicity. Such a view asserts that people of the same ethnicity share the same language, culture, religion and customs. The Rwanda government relies on faulty logic by asserting that since Rwandans share common language (Kinyarwanda), culture, religion and customs, it follows that they share the same ethnicity.

In fact, it is difficult to link ethnicity systematically to features of language use or cultural practices. There is some agreement, however, that ethnicity is a concept that is co-constructed through interaction and friction between groups of people who perceive varied differences (Fought 2006). Ethnicity is best seen as a multidimensional and mutable construct that may include, among others, perceptions of difference in dialect, diet, occupation, domicile, and possibly race (Eltringham 2004). Despite the lack of a stable definition for ethnicity, the construct is salient for people who believe themselves to be members of one group and not another.

Although the government in Kigali has asserted that ethnic differences cannot be applied to the Rwandan context, the persistent tensions in Rwanda are increasingly viewed as an identity-based conflict. The argument that there is only one Rwandan ethnicity is less useful than recognizing that Rwandans view themselves as belonging to different groups on the basis of many factors, including occupation, wealth, and regional differences. In modern-day Rwanda, language choice of French or English has become a factor in group affiliation determinations. As Hintjens has observed, language is now a proxy for identity (2008).

\footnotetext{
2 Many scholars have chronicled the events of the spring of 1994 and the stories of the survivors (Desforges 1999; Hatzfeld 2000; Pottier 2002; Prunier 1995, 2009a) and have analyzed the causes (Hatzfeld 2005a, b; Mamdani 2001). Western fascination with the story and collective guilt over non-intervention is apparent in reports from journalists (Berkeley 2002; Gourevitch 1998), recent movies such as Hotel Rwanda (George and Ho 2006) and Sometimes in April (Peck et al. 2005) and the popularity of a flood of first-person accounts by survivors, of which we can only highlight some of the more recent (e.g. Dallaire and Beardsley 2005; Ilibagiza and Erwin 2006; Mushikiwabo and Kramer 2006; Rusesabagina 2006).
} 
The definition of an ethnic group adopted by the Rwandan Senate asserts that shared language (Kinyarwanda), culture, religion and territory are enough to indicate shared ethnicity (Rwandan Senate 2006). This definition is adopted from theories of ethnicity as they have been developed in Western and Westernized academic circles, and is dependent on the claim to, among others, a common language. A government-supported research report provides an example of how this assertion has been incorporated into social and political discourse:

There has never been any "Hutuland" or "Tutsiland" or "Twaland." Rwandans had the same religion before colonialism and have always had one languageKinyarwanda. In the absence of clear-cut, distinctive criteria, the colonialists had to find ways and means of applying the divide and rule policy, and they invented theories of origin that have never been supported by any empirical evidence. This explains why many Rwandans attribute their social divisions to colonialists (Rutayisire et al. 2004, p. 323).

The concerted effort to alter how citizens think about their group affiliations, past and present, places significant restrictions on everyday discourse of the country. In 2004, the Rwandan government added a "divisionism" clause to its penal code, threatening imprisonment to anyone who speaks of ethnicity in a divisive manner and the death penalty for anyone who uses the media to incite Rwandans to violence (Lacey 2004). This concern for the use of the spoken and written word in Rwanda's public life to incite violence is well justified. The perpetrators of the Rwandan genocide used words to incite-through propaganda broadcast over the radio, through popular songs promoting violent acts, and through the explicit teaching of ethnic hatred in the school textbooks. Several highly publicized trials at the International Criminal Tribunal for Rwanda (ICTR) have led to the convictions of the propagandists who used the Milles-Collines Radio-TV and a host of extremist newspapers to spread ethnic hatred (Temple-Raston 2005). However, today restrictions on speech have been extended far beyond public figures and opinion makers.

In 2006, the Kagame government began a public campaign to eradicate "genocide ideology" from Rwandan society. Although this concept is derived from genocide studies and was used in the 2003 Constitution, it entered the social discourse on ethnicity in a new and more urgent way in 2006. "Genocide ideology" was defined by the Rwandan Senate as:

a set of ideas or representations whose major role is to stir up hatred and create a pernicious atmosphere favouring the implementation and legitimisation of the persecution and elimination of a category of the population (Rwandan Senate 2006, p. 16).

Chief among the "ideas or representations" is the use of ethnicity to promote fear, hatred and violence. Much of the interpretation of what constitutes genocide ideology has thus centered on the eradication of ethnicity, to the point where just giving credence to the existence of ethnicity in Rwanda is also punishable (Hintjens 2008; Morrill 2006). The law against genocide ideology has been vigorously interpreted to include a variety of actions that could be construed as discriminating 
against one group or promoting ethnic hatred. For instance, the Minister of Education was accused of "harbouring genocide ideology" after purportedly anonymous hate letters and syllabi containing theories about ethnic divisions were found in several schools (The New Times 2007a). Other incidents where students were reportedly made to wear different school uniforms according to their ethnicity, or where textbooks and literature inciting hatred were found in school libraries, made the national and international news (BBC News 2008; Musoni 2008).

Most relevant to this article, an incident cited in a 2008 report by the Rwandan legislative body demonstrates that refusal to teach English has been interpreted as evidence of genocidal ideology:

In one case, Ms. Alphonsine Musabyayezu the headmistress of Gakiarage Primary School in Nyagatare, Eastern Province was suspended by authorities and parents over "genocide ideology".

It is alleged that the headmistress dismissed and transferred teachers in the school basing on ideological leaning.

Ms Musabyayezu is also reported to have suspended the English section at the school, without any consultation with district leaders, a clear manifestation of her ill motives. [emphasis added] (Rwanda Development Gateway 2008).

The case of Ms. Musabyayezu suggests that our observations about the language policy, which we have been developing since 2001, are correct. The use of English is a political act that supports the Kagame government, with potentially serious consequences for resistance or non-compliance.

The emphasis on Kinyarwanda, though, obscures the roles that English and French play in Rwanda's divisions. Since it is now difficult to impossible to speak of Hutu, Tutsi or Twa ethnicities, group differences among educated Rwandans are now indexed by language use, but the groupings supercede "Hutu, Tutsi, and Twa." The next section shows how the country's elites have begun to redivide according to Tutsi Anglophone elite, mostly from Uganda, versus the Francophone elites, both Tutsi and Hutu, who were in Rwanda before the genocide, along with other returnees, mostly Tutsi, from Francophone countries.

\section{Indexing identity through language}

Omoniyi's (2003) explanation of social division makes space for the role of language in Rwanda's social tensions:

English and French may appear 'neutral' in contrast to indigenous languages; they are indeed ideologically positioned to serve local class interest. In other words, social and socio-economic difference together with multiethnicity is the divisive force in society (p. 147).

We have observed how language preferences, combined with information about the person's experiences during the war, could give us an indication of probable ethnicity. When we were working with a team of Rwandan collaborators to interview and hold focus groups at secondary schools in 2001, we could still ask 
direct questions about ethnicity. ${ }^{3}$ Speaking of ethnicity was not yet illegal, but it was strongly discouraged. We felt that the nature of our research, which addressed the teaching of history, a topic that cannot be disentangled from the history of ethnicity in Rwanda, necessitated obtaining data on the ethnicity of our research subjects. In our interview protocol, some of our questions included:

"How is ethnicity portrayed in the curriculum?"

"How should your school portray ethnicity?"

"What do you think about ethnicity?"

We asked the students, "Do you think your school is typical of other secondary schools with respect to what is being taught about ethnicity?" And we asked the parents, "What do you think parents want to see being taught about issues of ethnicity?"

The most delicate questions came right at the end of the teacher, student, and parent interviews:

Do you feel comfortable talking about your ethnicity?

If so, with which ethnic group do you identify?

If you were in Rwanda in 1991, what group was your family assigned in the 1991 census?

OR In the past, what ethnic group was your family identified as?

Although in many contexts, such a direct question would be considered leading, with subjects feeling that they would have to agree to such a conversation, in the Rwandan context, most would respond that they were not comfortable. We had to ask if they were willing to engage in this conversation. We then moved to a more indirect way to hold the conversation, but again, only if the subject was comfortable saying. If we were to ask these questions today, we could be accused of inciting ethnic division. For a Rwandan collaborator to ask these questions, the risks could be much graver-up to 20 years in jail. In light of these changes, the data we collected in 2001 is valuable in ways that we could not have foreseen at the time.

These questions on ethnicity were very complex even during interview training with U.S. and Rwandan team members. Much attention was given to the best way to phrase the questions; some team members suggested not asking the questions at all. The Rwandan interviewers differed in their openness about ethnicity. Some refused to tell their own affiliation and stated that they could not determine the ethnicity of other Rwandans. Others would tell their ethnicity when asked, and some said that they had no trouble determining the ethnicity of their fellow Rwandans. When the teams did their practice interviews, these questions evoked anger, defensiveness or offended retorts from some of their interviewees. The questions were also an issue in preliminary visits with school principals, and later in many of the interviews. The Rwandan team leader, however, was known to and trusted by teachers and school leaders and when we conducted the interviews was able to broker many such discussions, helping allay the subjects' discomfort. When we were able to proceed with the questions, we proceeded with care and sensitivity and without pressuring

\footnotetext{
${ }^{3}$ Most of these interviews were conducted in Kinyarwanda and later translated into French and English.
} 
subjects to respond. We also followed strict protocols to ensure confidentiality of the information and anonymity of the subjects. In the end, in most cases we collected useful and valuable information about the ethnic affiliations of our interviewees.

In order to encourage interviewees to speak frankly, we wanted to ensure that each two-person interviewing team sent out to the various schools would represent both Tutsi and Hutu ethnicities so that Tutsi could interview Tutsi and Hutu could interview Hutu. We learned about the perspectives and identities of each member through individual and group discussions, and then used this information when putting together the interview teams. Some of our Rwandan collaborators were Anglophone returnees who had grown up in Uganda, Tanzania or elsewhere; they were mostly Tutsi. Others were Tutsi survivors who had lost family members, or had fled to internal refugee camps protected by the RPF. We generally could use this information to make educated guesses about group affiliation and ethnic labeling, and we were able to rely on our lead research collaborators' local knowledge.

The division of the Rwandan populace as a result of the wars and genocide reflected co-construction of differences in ethnic and group affiliations that were not based solely on the voluntary affiliations of individuals, but on how other Rwandans viewed them. Those who had lived in Rwanda before 1994 and who were considered survivors were likely to be French speakers. They were also likely to be Tutsi, but not always, as many Hutu were also targeted during the genocide or mistaken for Tutsi. The Francophone Hutu members of our team had also experienced loss of spouses or had been compelled to flee.

On the basis of our observations, we asked our interviewees if they had ever left the country and lived elsewhere. Those who said yes, they had lived in the Congo or Tanzania since the genocide, were likely Hutu who fled to refugee camps to escape the victorious, and allegedly murderous, RPF forces. Any Anglophone who lived in Uganda, Tanzania or another Anglophone country before the war was likely of Tutsi background. They were members of Tutsi families that had fled earlier outbreaks of ethnically-motivated violence dating back to the colonial period. They were highly unlikely to be able to speak French, and many were determined not to learn the language. Most, but not all, were speakers of Kinyarwanda. However, some Tutsi fled to the Democratic Republic of Congo (Banyamulenge) or Burundi (Kirundi) before the war and were Francophone. Both countries have large groups of resident Tutsi who are speakers of other varieties of Kinyarwanda, also the result of successive waves of immigration from Rwanda. In the case of the Banyamulenge of the DRC, the immigration dates back to pre-colonial Rwanda. These distinctions are captured in Table 1.

Because country of origin, experiences before and right after the wars and genocide, and language spoken (French or English) reflect the impact that the war had on the lives of ordinary Rwandans, these three variables could facilitate an educated guess about the probable ethnicity of an individual. They indicate the labels that other Rwandans would be likely to assign to an individual, regardless of whether or not that individual claimed the ethnic affiliation or identity. These designations would have had significant impact on their life experiences. People who must flee ethnic pogroms or reprisals from murderous armies do not have the luxury of being able to argue about the existence of ethnicity or their 
Table 1 Distinguishing probable ethnic affiliation through most usual countries of residence prior to 1994, country of residence after the war (and likely experiences), and language preferences

\begin{tabular}{llll}
\hline $\begin{array}{l}\text { Country of residence } \\
\text { prior to 1994 }\end{array}$ & $\begin{array}{l}\text { Country of residence } \\
\text { after the war }\end{array}$ & Language preferences & $\begin{array}{c}\text { Likely ethnic } \\
\text { affiliation }\end{array}$ \\
\hline Rwanda & Rwanda (survivor) & French and Kinyarwanda & $\begin{array}{c}\text { Tutsi survivor } \\
\text { or Hutu }\end{array}$ \\
Rwanda & $\begin{array}{c}\text { Congo, Tanzania } \\
\text { (refugee) }\end{array}$ & French and Kinyarwanda & Hutu \\
Uganda & $\begin{array}{c}\text { Arrived in Rwanda } \\
\text { (returnee) }\end{array}$ & $\begin{array}{c}\text { English and Kinyarwanda (some } \\
\text { exceptions) }\end{array}$ & Tutsi \\
Congo or Burundi & $\begin{array}{c}\text { Arrived in Rwanda } \\
\text { (returnee) }\end{array}$ & $\begin{array}{c}\text { French and Kinyarwanda } \\
\text { (Banyamulenge, Kirundi) }\end{array}$ & Tutsi \\
\hline
\end{tabular}

membership in a particular group. Furthermore, this analysis does not imply that labels were always correctly assigned; indeed, many Rwandans died during the genocide as the result of mistaken ethnic identity. So we applied these guidelines cautiously, and with input from trusted Rwandan colleagues, mindful that there are cases of Rwandans whose experiences did not fit these categories. These guidelines also do not provide any definitive proof that ethnicity exists in Rwanda, but rather that the co-construction of ethnic affiliation in Rwandan society has a real and lasting impact on the lives of most Rwandans.

Our growing understanding of the relationship between language and ethnicity in Rwanda gave us a glimpse of the role that power dynamics play in Rwanda's language policy. Because members of the Rwandan elite are often former refugees who grew up in Uganda, English stands for political power. This was particularly so after 1994, when the newly arrived Anglophones established English as an official language and made little attempt to learn French. These returnees are now the establishment. They fought in the Rwandan Patriotic Front and raised war chests to support the effort; they hold the positions of power in Rwanda's political and business scenes, but they represent less than $5 \%$ of the population.

\section{The global popularity of English}

Our second point deals with claims that early English acquisition, even at the cost of academic L1 literacy, will support Rwanda's participation in the global economy. Privileging English over local languages and promoting English-based content instruction is a growing trend world-wide (Brock-Utne et al. 2005; Brocke-Utne 2002; Hornberger 2008). Rwanda is not alone in its efforts to adopt English as the language of instruction. Drastic shifts in language policy have occurred in other parts of Africa, and around the globe. Many nations, not only the newly-established and developing but also the developed, have given careful consideration to language policies regarding the adoption of English as a medium of content instruction. Several African countries, including Namibia (Harlech-Jones 1990), Botswana (Magogwe 2007), Mali (Canvin 2007), and South Africa (Heugh 2007; Uys et al. 
2007; Webb 2004), are attempting dramatic changes in their language policies. Elsewhere in the world, China (Hu 2007, 2008), Pakistan (Rassool and Mansoor 2007) and South Korea are increasing the status of English as a medium of instruction at ever-lower grade levels.

Literacy and language researchers and educators have voiced concerns over the abandonment of mother tongue instruction and the growing demand for contentbased instruction in English as a means of promoting English learning (Brock-Utne et al. 2005). In her collection of case studies on language-in-education policies in postcolonial countries, Rassool (2007) suggests that among the many ways that colonialism disrupted the "inner dynamic" of colonized societies, it altered collective beliefs and values. She describes a "colonial habitus," in Bourdieu's (1991) sense, and suggests that formerly colonized peoples "often make linguistic choices that reinforce existing social, political and economic inequalities; and, in doing so, they collude in their own collective disempowerment and/or dispossession" (p. 2).

This critical outlook problematizes English as an unquestioned good for enhancing educational and economic development. In Rwanda, public opinion on the subject of English-medium education is positive. Many see English as a necessary step towards prosperity and stability. The Great Lakes region of East Africa is dominated economically by the Anglophone countries: Kenya, Tanzania, and Uganda. English is a desired good: a ticket to better communication with the rest of the world and better knowledge transfer. Rwanda joined the East African Union in July 2009.

The cultural and linguistic capital that the Anglophone elite brought with them from abroad is a valuable commodity in the regional East African market and also in the global market. This linguistic capital is partly the reason for the positive outlook on English that our Rwandan interviewees in 2001 reported to us. Many of these interviewees, who were teachers, students and parents at secondary schools from different regions of the country, saw English as an important step towards greater opportunities for educational advancement and economic development. Most were optimistic about the prospects for successful integration of English as a language of instruction:

Interviewer (female, self-declared Tutsi; genocide survivor): In which language do you wish courses were taught?

Parent (male, self-declared Tutsi, genocide survivor): It depends on today's situation. We still face several problems due to pupils from the exterior [of the country]. They can't have their lessons in French language only. Also, pupils from the interior [of the country] can't easily have their lessons in English language. But, considering the way languages are seriously taught, it gives a hope that in [the near] future, all courses will be given out in both languages, French and English, because they [will be] taught since the early years of primary school. (November 19, 2001)

Interviewer (male, refused to declare but likely Hutu, refugee in 1994): What do you think about the national policy of having more than one official language for the schools? 
Teacher (female, self-declared Hutu, refugee in 1994): It is a good thing. I think it's good to teach in different languages; they should start this teaching from the primary school, then in secondary school, as it is done in the university. If the teacher is English speaking, he/she should teach in English and other will be able to follow. It is enrichment. It is really a gain for all the Rwandan people. (November 19, 2001)

Some of the reasons given for this enthusiasm for English included the better access to educational opportunities in Anglophone countries. A teacher described the anticipated results of the policy in the following terms:

Interviewer (female, self-declared Tutsi; genocide survivor): What do you think about the national policy of having more than one official language for the schools?

Teacher (female, refused to declare, genocide survivor): I think it's good. For instance, during the last years, people who were going to study in one of the Anglophone countries were compelled to learn English about one year. But since you know it, you can continue with your studies without delaying. (November 19, 2001)

Parents saw heightened enthusiasm for learning as a result of studying English:

Interviewer (female, self-declared Tutsi; genocide survivor): What have been the changes in schools since 1994?

Parent (male, self-declared Hutu, genocide survivor): Providing all of the children with schooling is all the government worries about. Children benefit by studying because the [one-language] system has changed. So, English has also been the language of instruction. Students are delighted about that. For instance, my daughter has been better at English since the 2nd form of common-core syllabus [equivalent to 8th grade]. She managed to converse with her English teacher. She liked English much more than French. This enabled her to have better memory for the former than the latter. Never have students had such an attitude before. (November 23, 2001)

These responses echo sentiments expressed by countless parents, students and teachers across the globe. The high status of English in an increasingly globalized market characterized by fluid transfer of knowledge and labor can mask the inherent risks posed by a rapid shift to English as the medium of instruction (Cummins 2000).

We did, however, hear some more complex reasons for the inclusion of English in the schools, which hint at the societal divisions that language proficiency indexed. Some teachers felt that requiring everyone to be bilingual would make it more difficult for Rwandans to be labeled according to their language and presumed ethnicity. This would reduce the risk of more social divisions. The viewpoint expressed here suggests that placing equal value on both French and English would help to build a bilingual society in which distinctions could not be made on the basis of language: 
Interviewer (female, self-declared Tutsi; genocide survivor): Which languages do you wish were the languages of instruction in the schools?

Teacher (male, self-declared Hutu, genocide survivor): If it was possible, I would like that everyone knows French and English. Kinyarwanda is the language of all Rwandans. I think there have been some problems of using English and French, even in University. If the problem persists, there will be divisions. For example, people from Uganda will be known and anyone would be able to identify them. In my opinion, all of us [should] know both French and English. (November 19, 2001)

These kinds of insights were in the minority, as Rwandans were then and are today under a great deal of pressure to echo the official rationale of their government, related almost exclusively to economic benefits.

\section{Unrealistic promises}

Our final point is that despite the promises, the much-anticipated outcomes of a rapid and early switch to English as the medium instruction are unlikely to be realized by the majority of Rwandan youth, just as most never learned French. There are several reasons for this prediction. Most schools remain poorly equipped and lack even basic supplies and textbooks. Many teachers are finding that they need to learn English while teaching it, or risk losing their jobs. School drop-out rates are high in Rwanda, due to factors such as lack of funds, parental attitudes, and high poverty levels necessitating that young children work at home to help the family to survive. Finally, and most importantly, academic literacy is not equivalent to conversational skill in a second language and takes much longer to develop, up to 7 years by some estimates.

Of course some will benefit from the new policy. Students who already know English from their home or country of origin will have a natural advantage. But students who lack sufficient access to English outside of school will be at greater risk of falling behind in their studies and failing to have access to secondary school, much less to university. The Anglophone elite will be assured of replicating their access to power with such policies.

The schools we visited in 2001 were scrambling to adapt to a French-English dual system, trying to find English-proficient teachers to comply with the new policy and teaching materials for them to use. Given the general lack of qualified teachers, many schools were not able to comply fully with the policy change. In practical terms, this resulted in a system in which Anglophone and Francophone teachers taught classes in their own languages, while the students struggled to keep up. In some cases, secondary schools made a rapid switch to Anglophone status, shifting to English-only instruction as staff and resources allowed (Gahigi 2008). A small number of new schools, mostly located in Kigali, offered instruction only in English. In other schools, French was the only medium of instruction. Many students entered the university without sufficient skill in one of the official languages, and had to devote their first year to intensive language study. In poorly 
funded schools, the overworked and often underprepared teaching staff was often not able to offer parallel courses in both French and English.

The interviewees who took a less optimistic view pointed out problems with funding and teacher education. Also, in the excerpts below, three students remark on the difficulty of following the lessons in an unfamiliar language. Their teachers were forced to fall back on Kinyarwanda, if they knew it, to make sure the students could understand their lessons. ${ }^{4}$

Interviewer (male, refused to declare but likely Hutu, refugee in 1994): What is your opinion about the education system in Rwanda? How are you taught, and how are studies are conducted in general?

Student (female, self-declared Tutsi, returnee): As teaching is concerned, it is well done and sometimes teachers encounter some problems. Only students face problems, for instance, those students like me from foreign countries had French as the language of instruction and when we arrived in Rwanda then in the fourth form of primary, we started using Kinyarwanda as language of instruction. French became forgotten in those circumstances. In the secondary schools, the situation remained the same as in primary but the really problems were faced by students because French as a language of instruction was compulsory. That situation bothered us because French became much more than that we had in primary.

Interviewer: Does it mean that the language of instruction at your school was only French?

Student: There was a kind of alternative. Many schools use alternative languages of instruction due to the low level of our understanding. Teachers are obliged to appeal to Kinyarwanda when students themselves complain that they don't understand.

Interviewer: Really, can't all the students understand ....?

Student: We don't understand very well. (November 20, 2001)

Interviewer (male, refused to declare but likely Hutu, refugee in 1994): What can you say about the education system before 1994?

Student (male, self-declared Hutu, status after war unknown): Before 1994, things were good because we used to study in one language only; there was no such thing as one person studying in French and another studying in English. There was even no discrimination in education because everybody was studying in French. Nowadays, there are some schools where they teach in English and others where they teach in French yet these languages are not understood at the same level by all people. This brings in difficulties and some people are not happy about it. (November 22, 2001)

\footnotetext{
${ }^{4}$ Since much of the teaching force was killed in 1994 or later convicted as perpetrators, many teachers today are not from Rwanda. Furthermore, membership in the East African Union makes it possible for Anglophone teachers from neighboring countries to compete for teaching jobs in Rwanda. Many of these teachers from other countries do not speak Kinyarwanda. We ran into cases in which the teacher and the students did not speak any language in common.
} 
Interviewer (female, Hutu, unknown): According to the national language policy, both French and English are supposed to be used in delivering lessons. What is your view if some lessons are given in French and others in English at your school?

Student (female, self-declared Hutu, genocide survivor): I feel it would cause some confusion among students; for instance, we are now obliged to speak French while we are at school. This would now mean that we would have to speak both English and French, yet students do not know adequate English and it would necessitate giving English more hours on the time-table. (December 2, 2001)

The problems faced by these students as they transitioned from home language to French, and now English, appear again and again in post-colonial African societies where ex-colonial languages maintain their status as the language of science, technology, power and influence. Their struggles are described by one African linguist as a form of torture: "To continue using English as a medium of instruction in post-primary education is a torture to most of our children; and it is unfair" (Malekela 2003, p. 111; cited in Prah 2008, p. 2). This statement was made in reference to education in neighboring Tanzania, where the legacy of British colonialism left English as a major language of education. The problem in Rwanda is similar.

In addition to the problems faced by the students, a school headmaster pointed out the very real obstacles, in terms of finance and human resources, to making the policy work.

Interviewer (male, refused to declare but likely Hutu, refugee in 1994): What do you think about the national policy of teaching in several languages? School headmaster (male, self-declared Hutu, refugee in 1994): Maybe at the university.

Interviewer: Yes, but at the secondary school and primary school, too.

School headmaster: How many people are able to teach in English? It depends. If they want utilization of these languages at the same rate, it requires much money. First of all, having the syllabus designed in those languages in which they want to teach. You must have qualified teachers who are able to teach in these languages. In my opinion, this is a too ambitious objective. (November 20, 2001)

These concerns are serious. Without adequate infrastructure, teacher training and educational materials, schools could not hope to adequately comply with the requirement to add English as a language of instruction. Asking teachers to work in a language in which they have not been adequately prepared will yield predictable results. Teachers, who must teach in a language that they don't know well, will resort to the vernacular to help the students understand their lessons. This often leads to underdevelopment of literacy in both languages. This problem was widespread in colonial school systems and remains an issue in many African countries today (Rassool 2007).

Blommaert $(2001,2008)$ has observed that literacy practices, even in the same language, do not often travel well, particularly when they emerge from contexts that 
are peripheral to the centers of power in the global economy. Texts written for communication beyond the locality may yield unpredictable results and prove to have limited usefulness. This is due to the considerable differences in access to the educational and material resources that support literacy in the literacy-permeated contexts in the developed world.

Blommaert (2001) cites as an example his study of the asylum application of a Burundese man whose written description of his home country was judged insufficient to prove his Burundese citizenship, presumably on the basis of unconventional "grassroots literacy" (Blommaert 2008, p. 195) features such as variable spellings, borrowed words from local languages, lists, drawings, and unconventional capitalization, punctuation, and genre. A Belgian judge had asked him to write everything he knew about Burundi, but did not find that the resulting French text qualified the author as a bona fide resident of Burundi.

Another example of this phenomenon comes from Blommaert's research in South Africa, where low academic achievement is a wide-spread problem in rural and non-white schools (Uys et al. 2007). He visited a rural secondary school where the students believed that studying English could have a real emancipatory and socioeconomic impact on their future prospects and could enable them to pursue middle-class living standards. Despite their high motivation to learn English well, the results of a questionnaire demonstrated that the English skills these students were acquiring might not be useful to them beyond their immediate community and school. A 16-year-old girl wrote the following answer to the question, "Which language do you like most, and why?" The text is reproduced here as Blommaert represented it, preserving the punctuation and capitalization of the student's work.

the language that I like at school to learn English because that Every-body

they learn English because is a very nice language to Everyone that

they want

to speak English. (p. 95)

According to Blommaert, the English used by the student reflects some local styles that were perfectly acceptable in the township where she lived. He asserts though,

Clearly, the actual language and literacy resources this girl has acquired do not match the criteria of upward globalized mobility. It will not get her out of the township; it is more likely to keep her in the township. It is locally good English that loses value and function as soon as it leaves that particular social space. And while in the township, this could qualify as good English and good writing, it becomes township English and grassroots literacy as soon as it leaves that space. (p. 95)

These accounts point to a worrisome potential that, for the majority of learners in Rwanda, the switch to English will sideline students who do not have a solid grasp of academic literacy in either their first language or English. Many people on the peripheries of the global community feel the pressure to learn English in order to improve the material and economic conditions of their lives, but there is no accompanying guarantee that early transition to English, at the expense of academic 
literacy in the mother language, will result in language skills that are sufficient for participation in a global "marketplace."

\section{An alternative: additive multilingual education}

These concerns do not by any means call for the abandonment of English as a very important part of the curriculum. What the voices of our interviewees suggest, and what Blommaert concurs with, is that switching to English as the sole language of instruction does not guarantee that students from impoverished communities will be guaranteed the benefits of participation in a global economy. Some of them will succeed, through grit, talent and assistance, but others will not, and they would be better prepared for the work if they also possessed advanced literacy skills in Kinyarwanda. A multilingual language policy (Annamalai 2003; Hornberger 2002) that attempts to develop a bilingual population accords all children a better chance at reaching the goal of participating in the growing Rwandan economy.

Kinyarwanda offers an underused opportunity for promoting universal education and higher rates of advanced literacy. An alternative policy of additive multilingualism (Annamalai 2003) would promote Kinyarwanda as a language of instruction, at least in the early grades, and maintaining it as older children begin to acquire proficiency in English, French, and other important regional ${ }^{5}$ and international languages. Hornberger's (1987) early work in Peru with additive bilingual education provides a model for successfully using the L1 as the medium of instruction.

Such a policy does not preclude a hierarchy of languages in which English is recognized as an essential skill, but it does help to prevent the perpetuation of inequality through unequal access to education and other resources on the basis of language (Annamalai 2003; Skutnabb-Kangas 1988). As a result, students who have received most of their education in French would not be penalized as they are today, required to take high-stakes examinations in a language they barely know. Their French proficiency would be seen as another resource, perhaps not as important as English (from the perspective of some), but a resource nevertheless that does not inhibit them from enjoying access to education and all of the benefits that come with it. Instead of being rushed into Anglophone curriculum, these students would be allowed to finish their schooling in French while also learning English intensively. Since the youngest students today would begin learning English as a subject, there would eventually be no need for Francophone schooling, and over time the system would be able to focus on developing bilingualism in English and Kinyarwanda. The current policy of abruptly switching from French to solely English in 1 or 2 years virtually ensures that all but the most privileged or talented of the nonAnglophone students will fail to finish secondary school. The current policy may serve the interests of an Anglophone elite that is focused on reinforcing its privilege,

\footnotetext{
5 Kinyarwanda is linguistically related to Kiswahili, which is the dominant African language for trade and commerce in the East African Union. Although the numbers are uncertain, an estimated $11 \%$ of Rwandans speak Kiswahili. Its importance for the economy makes it a logical choice for emphasis in school curricula.
} 
but it does not improve the long-term prospects of the country or of the majority of the population still living in crushing poverty.

Rwanda is particularly well-positioned to put its efforts into developing an educational program in which Kinyarwanda has an important role. Few African countries possess the advantage of having only one vernacular language that is spoken by the vast majority of its citizens, regardless of their background or ethnic affiliation (Calvet 1994). The success of Rwanda's efforts could challenge assumptions about the value and usefulness of African vernaculars and join a movement of African linguists and educationalists who support the development and harmonization of African languages:

... the argument that Africans should use their languages for 3-4 years at the primary school level and then move into the colonial languages is another way of saying that African languages are irredeemably doomed to backwardness and perdition. It is a lie which serves ultimately the maintenance of neocolonialism, at the cultural level. The idea also implies that the three to four year foundation is only meant to prepare African children to the later use of the colonial languages. (Prah 2008, p. 14)

The practice of schooling primary students in their mother language for a limited period (anywhere from 3 to 6 years), then moving them prematurely into doing their studies in a language that they have learned imperfectly due to lack of resources also has the result of producing a semiliterate population that is not only poorly versed in critical literacy skills, but is also poorly prepared to work in the developing economy envisioned by the shapers of language policy (Pimcock 2009; Prah 1993, 1995). This is further exacerbated when young children are required to begin learning in the new language from the beginning of the primary years.

From a purely utilitarian perspective, we argue that Rwanda is in great need of well-educated workers and can't afford to waste the potential of any child, particularly the children who will benefit more from a solid literacy background in Kinyarwanda than from a mediocre mastery of English. For many children, the sense of failure at not being able to learn English quickly enough to do well in their studies is a stigma that they will carry all their lives.

From the perspective of indigenous, disenfranchised communities that are understandably suspicious of any effort that they perceive as denying them access to the language of power (Annamalai 2003), an additive multilingual policy will make it possible for more than just a lucky few of their children to be successful in school.

Moving to a multilingual education policy would also challenge the hegemonic legacy of colonial languages and diminish the symbolic violence perpetrated by requiring English proficiency without making adequate resources available for the teaching and learning of English (Rassool 2007). This symbolic violence has been largely overlooked by the Anglophone press and development aid community, which has for many reasons been supportive of Rwanda's decision to switch to English. Some of these reasons are no doubt self-interest and an easy acceptance of the same ideology of global English that many Rwandans espouse. What has not been recognized is how such a politically fraught policy shift makes an already tense situation even more complex. 


\section{Conclusion}

Doing research in international contexts is an activity that for us has been frought with professional and ethical concerns about speaking for the other. We recognize that being a member of a culture provides access to information that is frequently not accessible to outsiders. In the case of current-day Rwanda, outsiders or expatriate Rwandans have the luxury of speaking critically about Rwanda's current language policy, whereas Rwandans living within the borders of their country do not. What should be the response by outsiders who are concerned about the new policy? Non-Rwandans can offer support for initiatives to promote greater use of Kinyarwanda as a vehicle for academic literacy. At the same time, though, they can assist individuals and schools with the mandated switch to English, as the consequences of not learning English are significant. They can share lessons from the U.S. and other countries on best practices for developing language skills in tandem with learning academic literacy and academic content. The Cognitive Academic Language Learning Approach (Chamot 2009) offers a potential model.

Rwanda's language policy can serve as an ongoing case study into the circuitous and sometimes contradictory role that the spread of English can play in postcolonial developing countries. English is seen as an important world language, but it is also the language of the elite in Rwanda, and a means for the elite to tighten its hold on privilege and power. Proficiency in English is seen as a key to economic development, business opportunities, and knowledge transfer, and yet transitioning students to English in Primary 1 does not allow them a chance to develop literacy in their own language and puts them at risk of never developing advanced literacy in English. For the students who until recently have studied mostly in French, the rush to English is frankly a disaster that puts them at severe risk of failure.

Given the politically sensitive nature of English due to its association with the English-speaking elite and the widespread adoption of English, these new policies create communicative inequality for Francophone Rwandans. Supporting advanced literacy in Kinyarwanda would send a strong message about the government's commitment to improving the lives of all Rwandans and ensuring the academic success of all students.

Open Access This article is distributed under the terms of the Creative Commons Attribution Noncommercial License which permits any noncommercial use, distribution, and reproduction in any medium, provided the original author(s) and source are credited.

\section{References}

Annamalai, E. (2003). Reflections on a language policy for multilingualism. Language Policy, 2(2), $113-132$.

BBC News. (2008, January 17). Rwanda 'still teaching genocide'. Retrieved January 21, 2009, from http://news.bbc.co.uk/go/pr/fr/-/2/hi/africa/7194827.stm.

Berkeley, B. (2002). The graves are not yet full: Race, tribe and power in the heart of Africa. New York: Basic Books.

Blommaert, J. (2001). Investigating narrative inequality: African asylum seekers stories in Belgium. Discourse and Society, 12(4), 413-449. 
Blommaert, J. (2008). Grassroots literacy: Writing, identity and voice in central Africa. London: Routledge.

Bourdieu, P. (1991). Language and symbolic power (G. Raymond \& M. Adamson, Trans.). Cambridge, MA: Harvard University Press.

Brocke-Utne, B. (Ed.). (2002). Language, democracy and education in Africa. Uppsala: Nordic Africa Institute.

Brock-Utne, B., \& Hopson, R. K. (Eds.). (2005). Languages of instruction for African emancipation: A focus on postcolonial contexts and considerations. Cape Town, South Africa: Centre for Advanced Studies of African Society (CASAS).

Calvet, L.-J. (1994). Les politiques de diffusion des langues en Afrique francophone. International Journal of the Sociology of Language, 107, 67-76.

Canvin, M. (2007). Language and education issues in policy and practice in Mali, West Africa. In N. Rassool (Ed.), Global issues in language, education, and development: Perspectives from postcolonial countries (pp. 157-186). Clevedon: Multilingual Matters.

Chamot, A. U. (2009). The CALLA handbook: Implementing the cognitive academic language learning approach (2nd ed.). New York: Pearson ESL.

Cummins, J. (2000). Language, power, and pedagogy: Bilingual children in the crossfire. Clevedon [England]; Buffalo [N.Y.]: Multilingual Matters.

Dallaire, R., \& Beardsley, B. (2005). Shake hands with the devil: The failure of humanity in Rwanda. Cambridge, MA: Da Capo.

Desforges, A. (1999). Leave none to tell the story. New York: Human Rights Watch.

Eltringham, N. (2004). Accounting for horror: Post-genocide debates in Rwanda. London: Pluto Press. Fought, C. (2006). Language and ethnicity. New York: Cambridge University Press.

Freedman, S. W., Kambanda, D., Samuelson, B. L., Mugisha, I., Mukashema, I., Mukama, E., et al. (2004). Confronting the past in Rwandan schools: Education as a tool for unity and reconciliation. In E. Stover \& H. M. Weinstein (Eds.), My neighbor, my enemy: Justice in the aftermath of genocide and ethnic cleansing (pp. 248-265). New York: Cambridge University Press.

Freedman, S. W., Weinstein, H., Murphy, K., \& Longman, T. (2008). Teaching history after identitybased conflicts: The Rwanda experience. Comparative Education Review, 52(4), 663-690.

Gahigi, M. (2008). Rwanda: English language teaching kicks off. AllAfrica.com Retrieved January 9 , 2009, from http://allafrica.com/stories/200812010940.html.

Gahindiro. (2007, July 8). Language crisis - Is the country French speaking or English speaking? The New Times Retrieved April 4, 2009, from http://www.allafrica.com.

George, T. \& Ho, K. (2006). Hotel Rwanda [motion picture]. U.S.A: Metro Goldwyn Mayer Home Entertainment.

Gettleman, J. (2008). Rwanda stirs deadly brew of troubles in Congo. New York Times. Retrieved December 4, 2008, from www.nytimes.com.

Gourevitch, P. (1998). We wish to inform you that tomorrow we will be killed with our families: Stories from Rwanda. New York: Picador.

Harlech-Jones, B. (1990). You taught me language: The implementation of English as a medium of instruction in Namibia. Oxford: Oxford University Press.

Hatzfeld, J. (2000). Life laid bare: The survivors in Rwanda speak (L. Coverdale, Trans.). New York: Other Press.

Hatzfeld, J. (2005a). Into the quick of life: The Rwandan genocide: The survivors speak (G. Feehily, Trans.). London: Serpent's Tail.

Hatzfeld, J. (2005b). Machete season: The killers in Rwanda speak (L. Coverdale, Trans. 1st American ed.). New York: Farrar, Straus and Giroux.

Heugh, K. (2007). Language and literacy issues in South Africa. In N. Rassool (Ed.), Global issues in language, education, and development: Perspectives from postcolonial countries (pp. 187-217). Clevedon: Multilingual Matters.

Hintjens, H. (2008). Post-genocide identity politics in Rwanda. Ethnicities, 8(1), 5-41.

Hornberger, N. (1987). Schooltime, classtime, and academic learning time in rural highland Puno, Peru. Anthropology \& Education Quarterly, 18(3), 207-221.

Hornberger, N. (2002). Multilingual language policies and the continua of biliteracy: An ecological approach. Language Policy, 1(1), 27-51.

Hornberger, N. (Ed.). (2008). Language policy and planning: Encyclopedia of language and education (2nd ed.). New York: Springer. 
Hu, Y. (2007). China's foreign language policy on primary English education: What's behind it? Language Policy, 6(3), 359-376.

$\mathrm{Hu}$, G. (2008). The misleading academic discourse on Chinese-English bilingual education in China. Review of Educational Research, 78(1), 190-226.

Ilibagiza, I., \& Erwin, S. (2006). Left to tell: Discovering God amidst the Rwandan holocaust. Carlsbad: Hay House, Inc.

Lacey, M. (2004, April 9). A decade after genocide, Rwandan government outlaws ethnicity. New York Times Retrieved April 4, 2009, from www.nytimes.com.

LeClerc, J. (2008). Rwanda. L'aménagement linguistique dans le monde. Retrieved April 3, 2009, from http://www.tlfq.ulaval.ca/axl/afrique/rwanda.htm.

Longman, T. (1999). Nation, race, or class? Defining the Hutu and Tutsi of Central Africa. In J. Feagin \& P. Batur-Banderlippe (Eds.), The global color line: Racial and ethnic inequality from a global perspective (Vol. 6).

Longman, T., \& Rutagengwa, T. (2004). Memory, identity and community in Rwanda. In H. M. Weinstein \& E. Stover (Eds.), My neighbor, my enemy: Justice in the aftermath of genocide and ethnic cleansing (pp. 162-182). New York: Cambridge University Press.

Magogwe, J. M. (2007). An investigation into attitudes and motivation of Botswana secondary school students towards English, Setswana, and indigenous languages. English World-Wide, 28(3), 311-328.

Malekela, G. (2003). English as a medium of instruction in post-primary education in Tanzania: Is it a fair policy? In B. Brock-Utne, Z. Desai \& M. Qorro (Eds.), Language of instruction in Tanzania and South Africa (pp. 102-113). Dar Es Salaam E \& D Ltd.

Mamdani, M. (2001). When victims become killers: Colonialism, nativism, and the genocide in Rwanda. Princeton, NJ: Princeton University Press.

Masagara, N. (2001). Conveying and evaluating speakers' commitment to telling the truth: The impact of European Christian missionaries on language use. Journal of Multilingual and Multicultural Development, 22(4), 325-338.

McCrummen, S. (2008, October 28). Rwandans say adieu to Francais: Leaders promote English as the language of learning, governance and trade. Washington Post Retrieved September 19, 2009, from LexisNexis Academic.

McGreal, C. (2008, November 23, 2009). Rose Kabuye, accused of involvement in assassination of Hutu president, seeks to expose 'abuse of international law'. guardian.co.uk Retrieved November 10, from guardian.co.uk.

Morrill, C. (2006). Show business and 'Lawfare' in Rwanda: Twelve years after the genocide. Dissent, 53(3), 14-20.

Mugabe, R. (2009). ULK Adopts English as the only language of instruction. All Africa.com Retrieved January 22, 2009, from www.allAfrica.com.

Munyankesha, P. (2004). Les defis du plurilinguisme officiel au Rwanda. Analyse sociolinguistique. Unpublished Ph.D., The University of Western Ontario (Canada), Canada.

Mushikiwabo, L., \& Kramer, J. (2006). Rwanda means the universe: A native's memoir of blood and bloodlines (1st ed.). New York: St. Martin's Press.

Musoni, E. (2008, January 29). MPs launch anti-genocide ideology campaign in schools. The New Times. Retrieved January 21, 2009, from http://www.allafrica.com.

Nambi, I. V. (2008, January 25, 2009). Embrace English, KIE Students Urged. All Africa Retrieved April 4, 2009, from http://allafrica.com/stories/200901230301.html.

National Public Radio. (2008, November 20). English to become official language in Rwanda. Retrieved April 4, 2009, from http://www.npr.org/templates/story/story.php?storyId=97245421.

Niyomugabo, C. (2009). Kinyarwanda-English dictionary. Kigali: Fountain Publishers.

Omoniyi, T. (2003). Local policies and global forces: Multiliteracy and Africa's indigenous languages. Language Policy, 2(2), 133-152.

Peck, R., Erhuero, O., Ebouaney, E., Elba, I., Winger, D., HBO Films., et al. (2005). Sometimes in April [videorecording]. [United States]: Home Box Office.

Pimcock, H. (2009). Language and education: The missing link. London: CfBT and Save the Children Alliance.

Pottier, J. (2002). Re-imagining Rwanda conflict, survival and disinformation in the late twentieth century. Available from http://www.netlibrary.com/urlapi.asp?action=summary $\& v=1 \&$ bookid= $=120$ 490.

Prah, K. K. (1993). Mother tongue for scientific and technological development in Africa. Bonn: German Foundation for International Development, Education, Science and Documentation Centre. 
Prah, K. K. (1995). African languages for the mass education of Africans. Bonn: German Foundation for International Development, Education, Science and Documentation Centre.

Prah, K. K. (2008). The language of instruction conundrum in Africa. Meeting on the Implications of Language for Peace and Development (IMPLAN). Retrieved April 4, 2009, from www.casas.co.za.

Prunier, G. (1995). The Rwanda crisis: History of a genocide. New York: Columbia University Press.

Prunier, G. (2009a). Africa's world war: Congo, the Rwandan genocide, and the making of a continental catastrophe. New York: Oxford University Press.

Prunier, G. (2009b). From genocide to continental war: The 'Congolese' conflict and the crisis of contemporary Africa. London: Hurst.

Rassool, N. (2007). Global issues in language, education and development: Perspectives from postcolonial countries. Buffalo: Multilingual Matters.

Rassool, N., \& Mansoor, S. (2007). Contemporary issues in language, education and development in Pakistan. In N. Rassool (Ed.), Global issues in language, education, and development: Perspectives from postcolonial countries (pp. 218-241). Clevedon: Multilingual Matters.

Rosendal, T. (2009). Linguistic markets in Rwanda: Language use in advertisements and on signs. Journal of Multilingual and Multicultural Development, 30(1), 19-39.

Rusesabagina, P. (2006). An ordinary man: An autobiography. New York: Viking.

Rutayisire, J., Kabano, J., \& Rubagiza, J. (2004). Redefining Rwanda's future: The role of curriculum in social reconstruction. In S. Tawil \& A. Harley (Eds.), Education, conflict and social cohesion (pp. 315-373). New York: UNESCO Publishing.

Rwanda Development Gateway. (2008, January 18). MPs in bid to stamp out 'genocide ideology'. Rwanda Development Gateway. Retrieved March 7, 2009, from http://www.rwandagateway.org/ article.php3?id_article $=7887$.

Rwandan, S. (2006). Rwanda: Genocide ideology and strategies for its eradication. Kigali: Republic of Rwanda.

Skutnabb-Kangas, T. M. M. L. (1988). Multilingualism and the education of minority children. In T. Skutnabb-Kangas \& J. Cummins (Eds.), Minority education: From shame to struggle (pp. 9-44). Philadelphia, PA: Multilingual Matters, Ltd.

Stover, E., \& Weinstein, H. M. (Eds.). (2004). My neighbor, my enemy: Justice in the aftermath of genocide and ethnic cleansing. New York: Cambridge University Press.

Temple-Raston, D. (2005). Justice on the grass: Three Rwandan journalists, their trial for war crimes, and a nation's quest for redemption. New York: Free Press.

The New Times. (2007a, December 7). Rwandan MPs accuse Education Ministry officials of genocide ideologies. The New Times Retrieved February 21, 2009, from Lexis-Nexis Academic.

The New Times. (2007b, February 21). The uniqueness of Kinyarwanda. The New Times. Retrieved April 4, 2009, from LexisNexis Academic.

The New Times. (2008, February 25). The language opportunity for "Ururimi". The New Times Retrieved February 21, 2009, from Lexis-Nexis Academic.

Uys, M., Van der Wait, J., \& Botha, S. (2007). English medium of instruction: A situation analysis. South African Journal of Education, 27(1), 69-82.

Wallis, A. (2006). Silent accomplice: The untold story of France's role in the Rwandan genocide. New York: Palgrave Macmillan.

Webb, V. (2004). African languages as media of instruction in South Africa: Stating the case. Language Problems and Language Planning, 28(2), 147-173.

Weinstein, H. M., Freedman, S. W., \& Hughson, H. (2007). School voices: Challenges facing education systems after identity-based conflicts. Education, Citizenship and Social Justice, 2(1), 41-71.

\section{Author Biographies}

Beth Lewis Samuelson received a Ph.D. in Language, Literacy and Culture Education from the University of California, Berkeley, USA, in 2004. She joined the faculty of the English department at Central Michigan University, USA, where she taught linguistics, English education and ESL/EFL. Since 2008, she has been Assistant Professor of Literacy, Culture and Language at the Indiana University School of Education in Bloomington, IN, USA. She has been involved in researching human rights and language education in Rwanda since 2001. 
Sarah Warshauer Freedman is Professor of Education at the University of California, Berkeley where she directed the National Center for the Study of Writing and Literacy from 1985-1996. Author of many journal articles and chapters, she also published with Simons, Kalnin, and Casareno, Inside City Schools: Literacy Learning in Multicultural Classrooms (1999, Teachers College Press), Exchanging Writing, Exchanging Cultures: Lessons in School Reform from the United States and Great Britain (1994, Harvard University Press), Response to Student Writing (1987, National Council of Teachers of English), and edited of The Acquisition of Written Language (1985, Ablex) and with Arnetha Ball, Bakhtinian Perspectives on Language, Literacy and Learning (2004, Cambridge University Press). Her current research, funded by the Spencer Foundation and in collaboration with Karen Murphy of Facing History and Ourselves, explores developing citizens in divided societies, with a focus on South Africa, Northern Ireland, and the United States. 